\title{
Exposure to ultraviolet radiation delays photosynthetic recovery in Arctic kelp zoospores
}

\author{
Michael Y. Roleda $\cdot$ Dieter Hanelt $\cdot$ Christian Wiencke
}

Received: 6 January 2006/ Accepted: 3 March 2006/Published online: 7 June 2006

(C) Springer Science+Business Media B.V. 2006

\begin{abstract}
Seasonal reproduction in some Arctic Laminariales coincides with increased UV-B radiation due to stratospheric ozone depletion and relatively high water temperatures during polar spring. To find out the capacity to cope with different spectral irradiance, the kinetics of photosynthetic recovery was investigated in zoospores of four Arctic species of the order Laminariales, the kelps Saccorhiza dermatodea, Alaria esculenta, Laminaria digitata, and Laminaria saccharina. The physiology of light harvesting, changes in photosynthetic efficiency and kinetics of photosynthetic recovery were measured by in vivo fluorescence changes of Photosystem II (PSII). Saturation irradiance of freshly released spores showed minimal $I_{k}$ values (photon fluence rate where initial slope intersects horizontal asymptote of the curve) values ranging from 13 to $18 \mu \mathrm{mol}$ photons $\mathrm{m}^{-2} \mathrm{~s}^{-1}$ among species collected at different depths, confirming that spores are low-light adapted. Exposure to different radiation spectra consisting of photosynthetically active radiation (PAR; 400-700 nm), PAR+UV-A radiation (UV-A; 320-400 nm), and PAR+ UV-A+UV-B radiation (UV-B; $280-320 \mathrm{~nm}$ ) showed that the cumulative effects of increasing PAR fluence and the
\end{abstract}

M. Y. Roleda ( $\square)$

Biologische Anstalt Helgoland, Alfred Wegener Institute for Polar and Marine Research, Marine Station, Postfach 18027483

Helgoland, Germany

E-mail: mroleda@awi-bremerhaven.de

D. Hanelt

Biozentrum Klein Flottbek, University of Hamburg, OhnhorstStr. 18, D-22609 Hamburg, Germany

C. Wiencke

Alfred Wegener Institute for Polar and Marine Research, Am

Handelshafen 12, 27570 Bremerhaven, Germany additional effect of UV-A and UV-B radiations on photoinhibition of photosynthesis are species specific. After long exposures, Laminaria saccharina was more sensitive to the different light treatments than the other three species investigated. Kinetics of recovery in zoospores showed a fast phase in $S$. dermatodea, which indicates a reduction of the photoprotective process while a slow phase in $L$. saccharina indicates recovery from severe photodamage. This first attempt to study photoinhibition and kinetics of recovery in zoospores showed that zoospores are the stage in the life history of seaweeds most susceptible to light stress and that ultraviolet radiation (UVR) effectively delays photosynthetic recovery. The viability of spores is important on the recruitment of the gametophytic and sporophytic life stages. The impact of UVR on the zoospores is related to the vertical depth distribution of the large sporophytes in the field.

Keywords Alaria esculenta $\cdot$ Kinetics $\cdot$ Laminaria digitata $\cdot$ Laminaria saccharina $\cdot$ Optimum quantum yield $\cdot$ P-I curve $\cdot$ Photosynthetic recovery $\cdot$ Saccorhiza dermatodea

$\begin{array}{ll}\begin{array}{ll}\text { Abbreviations } \\ \text { PAR }\end{array} & \begin{array}{l}\text { photosynthetically active radiation } \\ (=\mathrm{P})\end{array} \\ \text { UV-A } & \text { ultraviolet-A } \\ \text { UV-B } & \text { ultraviolet-B } \\ \text { PAR+UV-A } & (=\text { PA) } \\ \text { PAR+UV-A+UV-B } & (=\mathrm{PAB}) \\ I_{k} & \text { saturating irradiance } \\ \alpha & \text { photosynthetic efficiency } \\ \text { rETR }_{\text {max }} & \text { maximum relative electron transport } \\ & \text { rate } \\ \text { PSII } & \text { Photosystem II }\end{array}$




$\begin{array}{ll}\mathrm{F}_{\mathrm{v}} / \mathrm{F}_{\mathrm{m}} & \text { maximum potential quantum yield of } \\ & \text { PSII } \\ \mathrm{P}-\mathrm{I} \text { curve } & \text { photosynthesis-irradiance curve } \\ \tan \mathrm{h} & \text { hyperbolic tangent } \\ \mathrm{PFR} & \text { photon flux rate } \\ \text { CPDs } & \text { cyclobutane-pyrimidine dimers }\end{array}$

\section{Introduction}

Supply of spores and habitat availability are important resources in maintaining kelp communities in coastal marine environments. Once propagules are released into the water, a plume of spore cloud may drift downstream (Deysher and Norton 1982) and can be displaced laterally by currents and progressively diluted by turbulent mixing (Norton 1992). Zoospores can, therefore, be suspended within the euphotic layer of the water column for a period of time. Settling spores on substrate at great depths or under algal canopies experience a low-light microenvironment suitable for germination and growth. However, sinking velocity of spores is dependent on size, such that a $55 \mu \mathrm{m}$ non-motile carpospore of the florideophyte red alga Cryptopleura violacea (J. G. Ag.) Kylin released from a $6 \mathrm{~cm}$ tall gametophyte would take $10 \mathrm{~min}$ to reach the substrate (Coon et al. 1972), while a $156 \mu \mathrm{m}$ non-motile zygote of a fucoid brown alga Sargassum muticum (Yendo) Fensholt released from $1 \mathrm{~m}$ above the substrate would take 19-24 min (Norton and Fetter 1981). For kelp zoospores that are only $3-5 \mu \mathrm{m}$ in size, the viscosity of seawater will dominate and limit their swimming ability (Purcell 1977). The speed of flagellated cells of this size is approximately $120 \mu \mathrm{m} \mathrm{s}^{-1}$ (Kessler 1985). This means a travel time of about $2 \mathrm{~h}$ for a distance of $1 \mathrm{~m}$. Therefore, during the transitory planktonic phase, kelp zoospores can be exposed to environmental stress in particular high photon fluence rates and ultraviolet radiation (UVR) within the upper euphotic zone.

The potential for acclimation of the photosynthetic apparatus to changing radiation conditions is an important pre-requisite for the ecological success of algae. Further studies on this aspect, especially on the early life stages of macroalgae, should be carried out. For example, effect of UVR on the photosynthesis of reproductive cells has been studied only in few species of Laminariales (Dring et al. 1996; Wiencke et al. 2000; Roleda et al. 2005) and Ulvales (Cordi et al. 2001). Among the three Laminaria species in Helgoland, photoinhibition of zoospore photosynthesis to different light treatments, consisting of the whole light spectrum and excluding UV-B or UV-B+UV-A, and the capacity of recovery of their photosynthetic efficiencies was found to be related to the depth distribution of adult sporophytes (Roleda et al. 2005). Exposure to unnaturally high UVR fluence showed no full recovery in the photosynthetic capacities of gametophytes of the same species (Dring et al. 1996). In Arctic Laminaria digitata (Huds.) Lamour., photosynthesis of zoospores was significantly depressed under the whole light spectrum compared to the sporophytes (Wiencke et al. 2000).

Most data on the seaweed photosynthesis have been obtained from studies on their macroscopic developmental stages. Under strong light, Photosystem II (PSII) is inactivated and this phenomenon is called photoinhibition. Inactivation of oxygen-evolving complex is induced by blue light as well as UV light while red light inactivates the photochemical reaction center (Ohnishi et al. 2005). Photoprotection by increasing thermal energy dissipation controlled by carotenoids enables the seaweeds to recover rapidly after the offset of the stressful condition, formerly called dynamic photoinhibition (Osmond 1994). Photo-oxidative damage impairs the function of PSII. Photodamage is controlled by the steady-state oxidationreduction level of the primary quinone acceptor $\left(\mathrm{Q}_{\mathrm{A}}\right)$. Since the reduction state of $\mathrm{Q}_{\mathrm{A}}$ linearly increases with irradiance, the probability of photodamage increases under strong light (Melis 1999). While light damages PSII directly, oxidative stress during photosynthesis has been demonstrated to suppress the de novo synthesis of proteins, in particular, the D1 protein, which is required for the repair of PSII (Nishiyama et al. 2004, 2005). Photodamage or chronic photoinhibition mainly occurs in seaweeds growing in the lower sublittoral zone when exposed to high irradiances (Hanelt 1998). These species have a lower ability to down regulate photosynthesis through photoprotection or photoregulation processes (Hanelt et al. 2003).

UV-B radiation has more direct effects on the photosynthetic apparatus. Its absorption by aromatic and sulfhydrylcontaining biomolecules causes direct molecular damage (Vass 1997). Part of the D1/D2 heterodimer; the major structural complex within PSII are degraded (Richter et al. 1990), while absorption by DNA causes lesions primarily the formation of cyclobutane-pyrimidine dimers (CPDs) (Roleda et al. 2004, 2005). UV-A radiation, on the other hand, was found to be damaging for PSII by decreasing the electron flow from reaction centers to plastoquinone (Grzymski et al. 2001) affecting electron transport both at the water oxidizing complex and the binding site of the $\mathrm{Q}_{B}$ quinone electron acceptor (Turcsányi and Vass 2002). UV and blue light were also found to inactivate the oxygen-evolving complex of the PSII (Ohnishi et al. 2005). So we have good arguments that $\mathrm{UV}$ radiation impinging on the unicellular spores of seaweeds will increase their susceptibility to photodamage and affect the kinetics of recovery process after photoinhibition. 
Kinetics of recovery in photosynthetic efficiency after high light stress has been reported in gametophytes, young and old sporophytes of Laminaria saccharina (L.) Lamour. (Hanelt et al. 1997) and other Arctic marine algae (Hanelt 1998). To our knowledge, no study has been carried out on the kinetic of photosynthetic recovery in kelp zoospores. This study is aimed to investigate the impact of exposure to different spectral irradiances on the photosynthetic efficiency of zoospores after variable residence times of zoospores within the light saturating euphotic layer of the water column. This is simulated here by various exposure times to different spectral composition and subsequent exposure to dim white light comparable to the conditions on the sea bottom or under algal canopies. It is hypothesized that the degree of photoinhibition and recovery of photosynthesis after exposure to PAR and UVR of the Laminariales investigated is related to the upper depth distribution limit of the sporophytes. The results of the present study are of interest to estimate possible effects under a scenario of enhanced UV-B radiation due to stratospheric ozone depletion (Gathen et al. 1995; Stähelin et al. 2001), as biologically significant UV-B radiation (1\% UV-B) still penetrates depths of 4-7 m depending on cloud cover and water turbidity in Spitsbergen (Wiencke et al. 2006).

\section{Materials and method}

\section{Algal Material}

Fertile sporophytes of Saccorhiza dermatodea (Pyl.) J. Ag., Alaria esculenta (L.) Grev., Laminaria digitata and $L$. saccharina were collected between May and June 2004 by SCUBA divers in Kongsfjorden at Prins Heinrichøya or Blomstrandhalvøya close to Ny Ålesund (Spitsbergen, $78^{\circ} 55^{\prime} \mathrm{N}, 11^{\circ} 56^{\prime} \mathrm{E}$ ). Blades with sori were excised from five different individuals per species (representing the five replicates), cleaned of epiphytes, blotted with tissue paper and kept in darkness in a moist chamber at $0^{\circ} \mathrm{C}$ overnight to maximum of 2 days. To induce rapid release of zoospores, sori were immersed in $5-10 \mathrm{ml}$ filtered $(0.2 \mu \mathrm{m}$ pore size $)$ seawater at $\pm 15^{\circ} \mathrm{C}$ and exposed to natural light close to a window (Wiencke et al. 2006). The initial zoospore density was counted by use of a Neubauer chamber (Brand, Germany). Stock suspensions were diluted with filtered seawater to give spore densities between $4 \times 10^{5}-5 \times 10^{5}$ spores $\mathrm{ml}^{-1}$ among the five replicates.

\section{Irradiation treatments}

Photosynthetically active radiation (PAR) was provided by white fluorescent tubes (Osram, L65 Watt/25S, Munich,
Germany). UVR was generated by UVA-340 fluorescent tubes (Q-Panel, Cleveland,OH, USA), emitting a spectrum similar to solar radiation in the range $295-340 \mathrm{~nm}$. Cell culture dishes $(35 \mathrm{~mm} \times 10 \mathrm{~mm}$ Corning, Corning Inc., NY, USA) were covered with one of the following filters to cut off different wavelength ranges from the spectrum emitted by the fluorescent tubes: Ultraphan transparent (Digefra GmbH, Germany); Folanorm (Folex GmbH, Germany) or Ultraphan URUV farblos corresponding to the PAR+UV-A+UV-B (PAB), PAR+UV-A (PA), and PAR (P) treatments, respectively. The spectral properties of the foils used are published elsewhere (Bischof et al. 2002). UVR was measured using a cosine sensor connected to a UV-VIS Spectrometer (Marcel Kruse, Bremerhaven, Germany) below the cut-off filters at $5.65 \mathrm{~W} \mathrm{~m}^{-2} \mathrm{UV}-\mathrm{A}$ and $0.47 \mathrm{~W} \mathrm{~m}^{-2}$ UV-B. PAR was measured using a cosine quantum sensor attached to a LI-COR data logger (LI-1000, LI-COR Biosciences, Lincoln, Nebraska, USA) to be $21.8 \mu \mathrm{mol}$ photons $\mathrm{m}^{-2} \mathrm{~s}^{-1}\left(\sim 4.69 \mathrm{~W} \mathrm{~m}^{-2}\right)$.

\section{Chlorophyll fluorescence measurements}

Photosynthetic efficiency was measured as variable fluorescence of PSII determined using a Water Pulse Amplitude Modulation fluorometer (Water-PAM) connected to a PC with WinControl software (Heinz Walz GmbH, Effeltrich, Germany). Immediately after adjustment of spore density (not exceeding $1 \mathrm{~h}$ after spore release), the spore suspension was filled into $5 \mathrm{ml}$ Quartz cuvettes and the maximum quantum yield $\left(F_{\mathrm{v}} / F_{\mathrm{m}}\right)$ was measured at time zero $(n=5)$ as described by Hanelt (1998) and designated as control. After 3 min dark incubation, $F_{\mathrm{o}}$ was measured with red measuring light pulse $\left(\sim 0.3 \mu \mathrm{mol}\right.$ photon $\mathrm{m}^{-2} \mathrm{~s}^{-1}$, $650 \mathrm{~nm}$ ), and $F_{\mathrm{m}}$ was determined with a $600 \mathrm{~ms}$ completely saturating white light pulse $(\sim 275 \mu$ mol photon $\mathrm{m}^{-2} \mathrm{~s}^{-1}$ ). Photosynthesis (in terms of relative electron transport rate, $\mathrm{rETR}=\mathrm{PFR} \times \Delta \mathrm{F} / \mathrm{Fm}$ ') versus irradiance curves (P-I curve) was also measured in the time zero control ( $n=3$, chosen at random from the five replicates) as described by Bischof et al. (1998). The hyperbolic tangent model of Jassby and Platt (1976) was used to estimate P-I curve parameters described as:

$\mathrm{rETR}=\mathrm{rETR}_{\max } * \tan \mathrm{h}\left(\alpha * I_{\mathrm{PAR}} * \mathrm{rETR}_{\max }^{-1}\right)$

where $\mathrm{rETR}_{\max }$ is the maximum relative electron transport rate, $\tan \mathrm{h}$ is the hyperbolic tangent function, $\alpha$ is the electron transport efficiency and $I$ is the photon fluence rate of PAR. The saturation irradiance for electron transport $\left(I_{k}\right)$ was calculated as the light intensity at which the initial slope of the curve $(\alpha)$ intercepts the horizontal asymptote $\left(\mathrm{rETR}_{\max }\right)$. The saturating photosynthetic photon flux density (PPDF) value at which photosynthesis is at $95 \%$ of 
the maximum value $\left(I_{0.95}\right)$ is directly proportional to $I_{k}$ and can be derived using the equation $I_{0.95}=\tan ^{-1}(0.95) I_{k}$ (Chalker et al. 1983). Curve fit was calculated with the Solver Module of MS-Excel using the least squares method comparing differences between measured and calculated data.

Controls measured at time zero were filled into corresponding culture dishes. To evaluate the effect of different radiation treatments and exposure times, $5 \mathrm{ml}$ of fresh spore suspension were filled into each $35 \mathrm{~mm} \times 10 \mathrm{~mm}$ cell culture dish and exposed to the three radiation conditions in a series of time treatments $(1,4$, and $8 \mathrm{~h} ; n=5$ per treatment combination) at $7 \pm 1{ }^{\circ} \mathrm{C}$. After treatments, $F_{\mathrm{v}} /$ $F_{\mathrm{m}}$ was determined and the spore suspension was returned to the same culture dish and cultivated under dim white light $\left(8 \pm 2 \mu \mathrm{mol}\right.$ photons $\left.\mathrm{m}^{-2} \mathrm{~s}^{-1}\right)$ at the same temperature for recovery. Time zero control was also maintained at the same condition. Measurements of photosynthetic recovery in time-series were made after $2,4,8,24$, and $48 \mathrm{~h}$ in dim white light condition. To eliminate a possible handling effect due to repeated measurements, $F_{\mathrm{v}} / F_{\mathrm{m}}$ was also measured in time zero control at time-series in synchrony with recovery of treated samples, and now designated as disturbed control. Another set of controls in parallel to each replicate was separately prepared and cultured immediately in dim white light after release designated as undisturbed control. Photosynthetic efficiency of undisturbed controls was measured at the end of the recovery period $(48 \mathrm{~h})$ of the experiment. Settled and germinating spores were slowly resuspended by sucking and jetting the medium against the bottom of the culture dish using Eppendorf pipettes. Time-series recovery in optimum quantum yield of zoospores after exposure to different spectral irradiance was expressed as percent recovery of disturbed control as:

$\operatorname{Rec}_{F \mathrm{v} / F \mathrm{~m}}^{t}=100 *\left(C_{F \mathrm{v} / F \mathrm{~m}}^{t}-\left(C_{F \mathrm{v} / F \mathrm{~m}}^{t}-T_{F \mathrm{v} / F \mathrm{~m}}^{t}\right)\right) / C_{F \mathrm{v} / F \mathrm{~m}}^{t}$

where $T_{F v / F m}$ is the optimum quantum yield of treated sample after recovery at time t $(2,4,8,24$, and $48 \mathrm{~h})$ and $C_{F \mathrm{v} / F \mathrm{~m}}$ is the corresponding optimum quantum yield of control at time $t$.

\section{Statistical analysis}

Data were tested for homogeneity (Levene Statistics) and normality (Kolmogorov-Smirnov test) of variance. Corresponding transformations (square roots) were made to heteroskedastic and non-normal data. Photosynthetic response to varying irradiance, exposure time and interaction effect were tested using multiple analyses of variance (MANOVA, $P<0.05$ ). Time series measurements on the kinetics of photosynthetic recovery were subjected to repeated measures analysis of variance (RMANOVA, $P<0.05)$ to determine the effect of pre-exposure irradiance treatments of $\mathrm{P}, \mathrm{PA}$, and $\mathrm{PAB}$ separately among different exposure times. All analyses were followed by Duncan's multiple range test (DMRT, $P=0.05$ ). Statistical analyses were made using SPSS program (SPSS, Chicago, IL, USA).

\section{Results}

The $I_{k}$ values of zoospores of all studied species were very low. Highest saturating irradiance $\left(I_{k}\right)$ was measured in zoospores of the shallow water species Saccorhiza dermatodea at $17.9 \mu \mathrm{mol}$ photon $\mathrm{m}^{-2} \mathrm{~s}^{-1}$ (Fig. 1; Table 1). Lower $I_{k}$ values were measured in the upper sublittoral species Alaria esculenta at $16.2 \mu \mathrm{mol}$ photon $\mathrm{m}^{-2} \mathrm{~s}^{-1}$ and the mid sublittoral Laminaria digitata at $15.4 \mu \mathrm{mol}$ photon $\mathrm{m}^{-2} \mathrm{~s}^{-1}$ and lowest in the mid- to lower-sublittoral species L. saccharina at $12.6 \mu \mathrm{mol}$ photon $\mathrm{m}^{-2} \mathrm{~s}^{-1}$. The maximum relative electron transport rate $\left(\mathrm{rETR}_{\max }\right)$ was highest in $S$. dermatodea and in a lower, similar range in the other species studied. In $L$. saccharina photoinhibition was observed at photon fluence rate above $80 \mu \mathrm{mol}$ photon $\mathrm{m}^{-2} \mathrm{~s}^{-1}$, but not in other species. The values of alpha were similar in all species and varied between 0.082 and 0.137 (Table 1).

Maximal quantum yield of the PSII $\left(F_{\mathrm{v}} / F_{\mathrm{m}}\right)$ in the time zero control was highest in $S$. dermatodea $(0.550 \pm 0.05)$, but not significantly different between $L$. digitata $(0.440 \pm 0.04), \quad$ L. saccharina $(0.439 \pm 0.04)$ and A. esculenta $(0.432 \pm 0.04)$. Time-series measurements of the disturbed controls exhibited no significant handling effect on the photosynthetic efficiency of zoospores (Table 2). Comparison between disturbed and undisturbed control after $48 \mathrm{~h}$ showed no significant variation in $S$. dermatodea, A. esculenta and $L$. digitata. Significantly higher $F_{\mathrm{v}} / F_{\mathrm{m}}$ was, however, observed in disturbed compared to undisturbed control in $L$. saccharina (T-test, $P<0.001)$.

Exposure to increasing time of PAR significantly reduced optimum quantum yield $\left(F_{\mathrm{v}} / F_{\mathrm{m}}\right)$ of all species investigated (Fig. 2). After $1 \mathrm{~h}$ exposure to PAR, photosynthetic efficiencies of both $S$. dermatodea and A. esculenta was least affected compared to $L$. digitata and L. saccharina. Increasing exposure time to PAR had a low additional effect on the $F_{\mathrm{v}} / F_{\mathrm{m}}$ of $S$. dermatodea while $L$. saccharina was most sensitive to increasing fluence of PAR. A sharp decline in the $F_{\mathrm{v}} / F_{\mathrm{m}}$ was observed in A. esculenta compared to L. digitata (Fig. 2). Light supplemented with UV-A radiation significantly decreased photosynthetic efficiency by $7 \%-96 \%$ in all species 

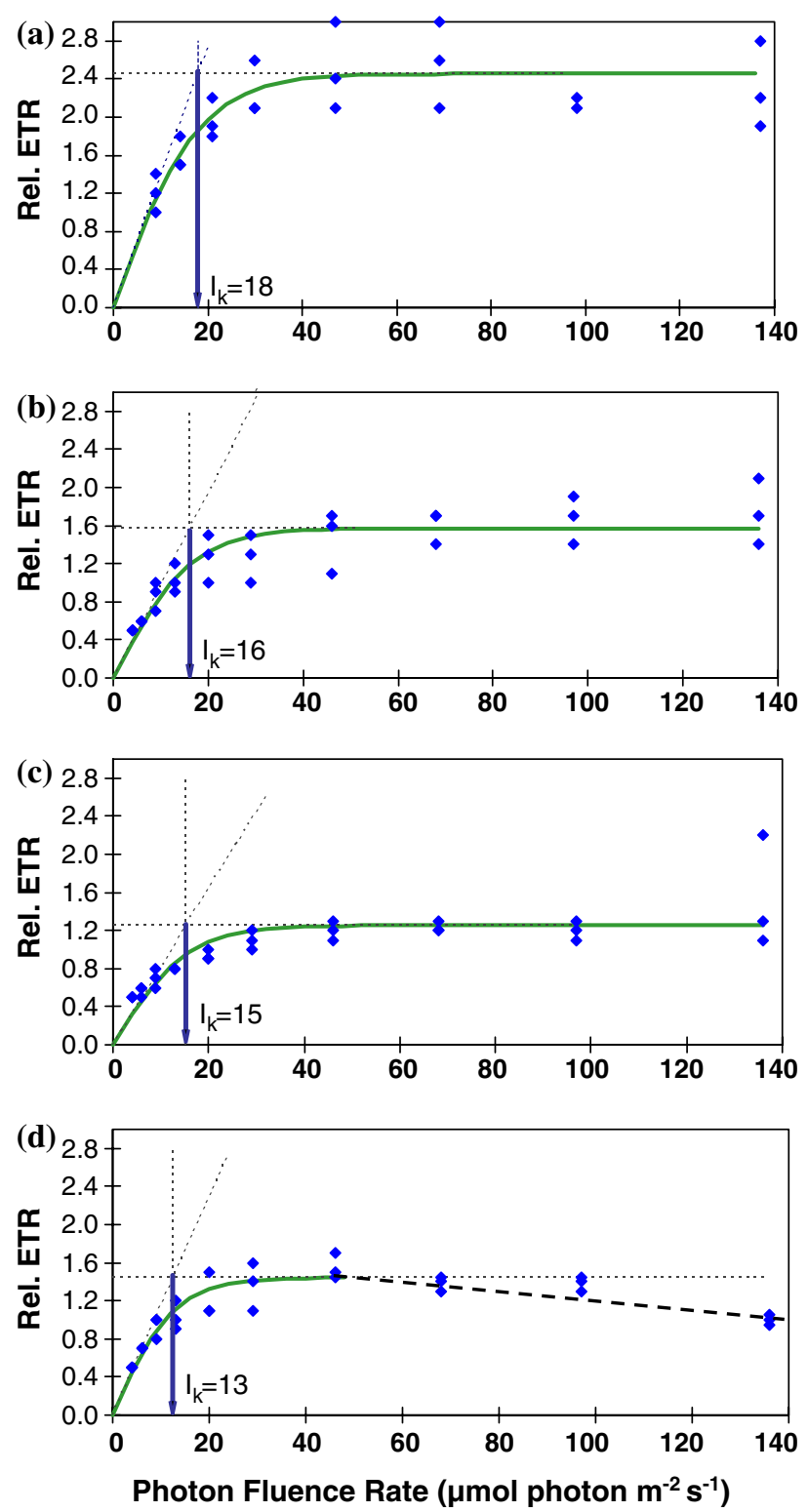

Fig. 1 Photosynthetic performance (P-I curve) of zoospores from (a) Saccorhiza dermatodea (b) Alaria esculenta (c) Laminaria digitata and (d) Laminaria saccharina $(\mathrm{n}=3)$ immediately after release from the sori. PFR is the respective photon fluence rate of actinic white light and rETR is the relative electron transport rate, an index of light harvesting and subsequent charge separation in PS II and PS I initiating electron transport and production of NADPH and ATP. Saturating irradiance $\left(I_{k}\right)$ is estimated as the point at which the initial slope crosses maximum photosynthesis $\left(\mathrm{rETR}_{\max }\right)$ using the hyperbolic tangent model of Jassby and Platt 1976

studied. The additional effect of UV-B radiation (PAB treatment) was only observed after $1 \mathrm{~h}$ exposure in $S$. dermatodea and A. esculenta. Under longer exposure time, no significant difference was observed between PA and PAB treatments (Fig. 2a, b). Conversely, in L. digitata and $L$. saccharina, no significant difference was observed between PA and PAB treatments after $1 \mathrm{~h}$ exposure but significant additional effect of UV-B was observed at
Table 1 Photosynthesis-irradiance curve parameters estimated using the hyperbolic tangent equation of Jassby and Platt 1976 and Chacker et al. 1983

\begin{tabular}{lllll}
\hline Species & $\begin{array}{l}I_{k}(\mu \mathrm{mol} \\
\left.\text { photon } \mathrm{m}^{-2} \mathrm{~s}^{-1}\right)\end{array}$ & $\begin{array}{l}I_{0.95}(\mu \mathrm{mol} \\
\left.\text { photon } \mathrm{m}^{-2} \mathrm{~s}^{-1}\right)\end{array}$ & $\mathrm{ETR}_{\max }$ & Alpha \\
\hline S. dermatodea & 17.9 & 33.0 & 2.45 & 0.137 \\
A. esculenta & 16.2 & 29.3 & 1.57 & 0.097 \\
L. digitata & 15.4 & 27.5 & 1.25 & 0.082 \\
L. saccharina & 12.6 & 23.8 & 1.44 & 0.115 \\
\hline
\end{tabular}

$I_{k}$ is the light intensity at which the initial slope of the curve $(\alpha)$ intercepts the horizontal asymptote, the maximum relative electron transport rate $\left(\mathrm{rETR}_{\max }\right) . I_{0.95}$ is the saturating photosynthetic photon flux density (PPDF) value at which photosynthesis is at $95 \%$ of the maximum value $\left[I_{0.95}=\tan ^{-1}(0.95) I_{k}\right]$

longer exposure time (Fig. 2c, d). Multiple analyses of variance (MANOVA, $P<0.001$ ) demonstrated significant effects of irradiance and exposure time in all species investigated (Table 3). Duncan's multiple range test (DMRT, $P=0.05$ ) showed significantly higher reduction in photosynthetic efficiencies of zoospores exposed to the whole light spectrum compared to light without UV-B radiation and to PAR alone ( $\mathrm{PAB}>\mathrm{PA}>\mathrm{P}$ ) among $S$. dermatodea, A. esculenta, and $L$. saccharina. In $L$. digitata, reduction in optimum quantum yield of zoospores exposed to light treatments supplemented with UV-A alone or UV-A+UV-B was not significantly different $(\mathrm{PAB}=\mathrm{PA}>\mathrm{P})$. Fluence as a function of different exposure times, exhibits a significantly different effect on $F_{\mathrm{v}} / F_{\mathrm{m}}$ in $S$. dermatodea, A. esculenta, L. saccharina $(8 \mathrm{~h}>4 \mathrm{~h}>1 \mathrm{~h})$, and L. digitata $(8 \mathrm{~h}=4 \mathrm{~h}>1 \mathrm{~h})$.

The kinetics of photosynthetic recovery in zoospores was observed to be different between species, spectral treatments and exposure times (Fig. 3). In general, photosynthetic recovery in $S$. dermatodea was faster under all light treatments and exposure times compared to the three other species investigated. Regardless of exposure time, recovery after exposure to PAR (=P) alone was already 91\%-96\% after $2 \mathrm{~h}$ and complete recovery was already observed after $4 \mathrm{~h}$. Recovery in zoospores exposed to light supplemented with UV-A (=PA) was lower but not significantly different compared to $\mathrm{P}$ treatment at $1 \mathrm{~h}$ exposure. Photosynthetic recovery of spores pre-exposed for 4 or $8 \mathrm{~h}$ to PA was delayed by $6 \%-10 \%$ during the first $2 \mathrm{~h}$, respectively. A minimum of $8 \mathrm{~h}$ post-cultivation in dim white light was required for complete recovery of their photosynthetic efficiency. In light supplemented with UV-A and UV-B (=PAB), recovery was significantly different with $\mathrm{P}$ but not with PA. Pre-exposure for 4 to $8 \mathrm{~h}$ $\mathrm{PAB}$ further delayed photosynthetic recovery. Complete recovery of photosynthetic efficiency of PAB-treated samples was observed only after $24 \mathrm{~h}$ culture in dim white light.

Photosynthetic recovery after $2 \mathrm{~h}$ in A. esculenta preexposed to $1 \mathrm{~h} \mathrm{P}$ treatment was $87 \%$ and complete recov- 


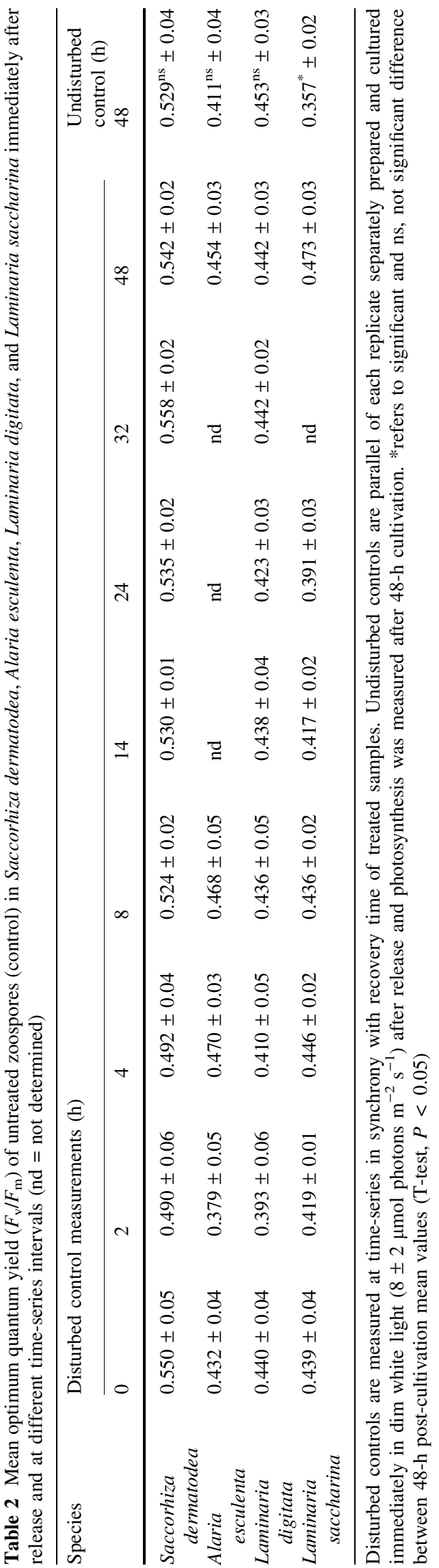

ery was observed only after $8 \mathrm{~h}$ in dim white light. This is $4 \mathrm{~h}$ more than the time required for $S$. dermatodea to fully recover its photosynthesis. In samples exposed for $1 \mathrm{~h}$ to UVR, photosynthetic recovery after $2 \mathrm{~h}$ was only $59 \%$ and $37 \%$ in PA and PAB, respectively. Complete recovery was, however, observed after $48 \mathrm{~h}$. Pre-exposure to $4 \mathrm{~h}$ of the three radiation condition $(\mathrm{P}, \mathrm{PA}, \mathrm{PAB})$ showed linear increase in photosynthetic recovery within $2-8 \mathrm{~h}$ postcultivation. However, only partial recovery was observed in zoospores exposed to $\mathrm{P}$ and lower $F_{\mathrm{v}} / F_{\mathrm{m}}$ was also measured in PA and PAB treatments.

In $L$. digitata, recovery of photosynthetic capacity after $1 \mathrm{~h}$ pre-exposure to the three radiation conditions was slower relative to $S$. dermatodea and A. esculenta. Values of photosynthetic efficiency comparable to the control were achieved only after $24 \mathrm{~h}$ post-cultivation in low white light. After $4 \mathrm{~h}$ pre-exposure treatments, photosynthetic recovery was further decreased in all treatments. Exposure to $8 \mathrm{~h} \mathrm{P}$ and PA treatments did not show further decrease in optimum quantum yield suggesting acclimation (Fig. 3c). Slightly higher photosynthetic recovery was observed in $8 \mathrm{~h}$ P- and PA- pre-exposed samples compared to $4 \mathrm{~h}$ P- and PA- pre-exposed samples (Fig. 3c). However, preexposure to $8 \mathrm{~h} \mathrm{PAB}$ was found to further delay kinetics of photosynthetic recovery.

Photosynthesis of $L$. saccharina was most sensitive to changes in spectral irradiance and fluence. After $1 \mathrm{~h}$ preexposure to $\mathrm{P}$, photosynthetic efficiency recovered to $82 \%$ after $2 \mathrm{~h}$. In the following measurements, there was a gradual linear increase attaining full photosynthetic recovery after $8 \mathrm{~h}$. Pre-exposure to $\mathrm{P}$ for 4 and $8 \mathrm{~h}$ resulted in a stronger photoinhibition and a steeper linear increase in photosynthetic efficiency. No full recovery was observed after $24 \mathrm{~h}$ post-culture in zoospores preexposed to $8 \mathrm{~h}$ PAR. Exposure to light supplemented with UVR showed different trends in recovery kinetics between exposure treatments. After $1 \mathrm{~h}$ pre-exposure to $\mathrm{PA}$ and $\mathrm{PAB}$, there was a steep linear increase in photosynthetic recovery between $2 \mathrm{~h}$ and $8 \mathrm{~h}$ post-cultivation. However, no further recovery was observed after $24 \mathrm{~h}$ post-cultivation. In 4-h PA and PAB pre-exposed samples, a steep linear increase in photosynthetic efficiency was observed between $1 \mathrm{~h}$ and $24 \mathrm{~h}$ post-culture but mean recovery was lower compared to zoospores exposed only to $1 \mathrm{~h}$ pre-treatment. Zoospore exposed to $8 \mathrm{~h} \mathrm{PAB}$ was only able to recover $31 \%$ of its photosynthetic capacity after $24 \mathrm{~h}$ post-cultivation.

Repeated measures analysis of variance (RMANOVA, $P<0.01$ ) showed significant effects of irradiance on the kinetics of photosynthetic recovery of all species investigated. Duncan's multiple range test (DMRT, $P=0.05$ ) demonstrates a faster recovery in spores pre-treated with different fluence of PAR alone (Fig. 3). Supplement of 
Fig. 2 Mean optimum quantum yield $\left(F_{\mathrm{v}} / F_{\mathrm{m}}\right)$ of zoospores during treatment to photosynthetically active radiation $(\mathrm{PAR}=\mathrm{P}), \mathrm{PAR}+$ UV-A (PA), and PAR + UV-A + UV-B (PAB) at different exposure times in (a) Saccorhiza dermatodea (b) Alaria esculenta (c) Laminaria digitata and (d) Laminaria saccharina. Vertical bars are standard deviations $(\mathrm{SD}, \mathrm{n}=5)$. Multiple analysis of variance (MANOVA) is presented in Table 3
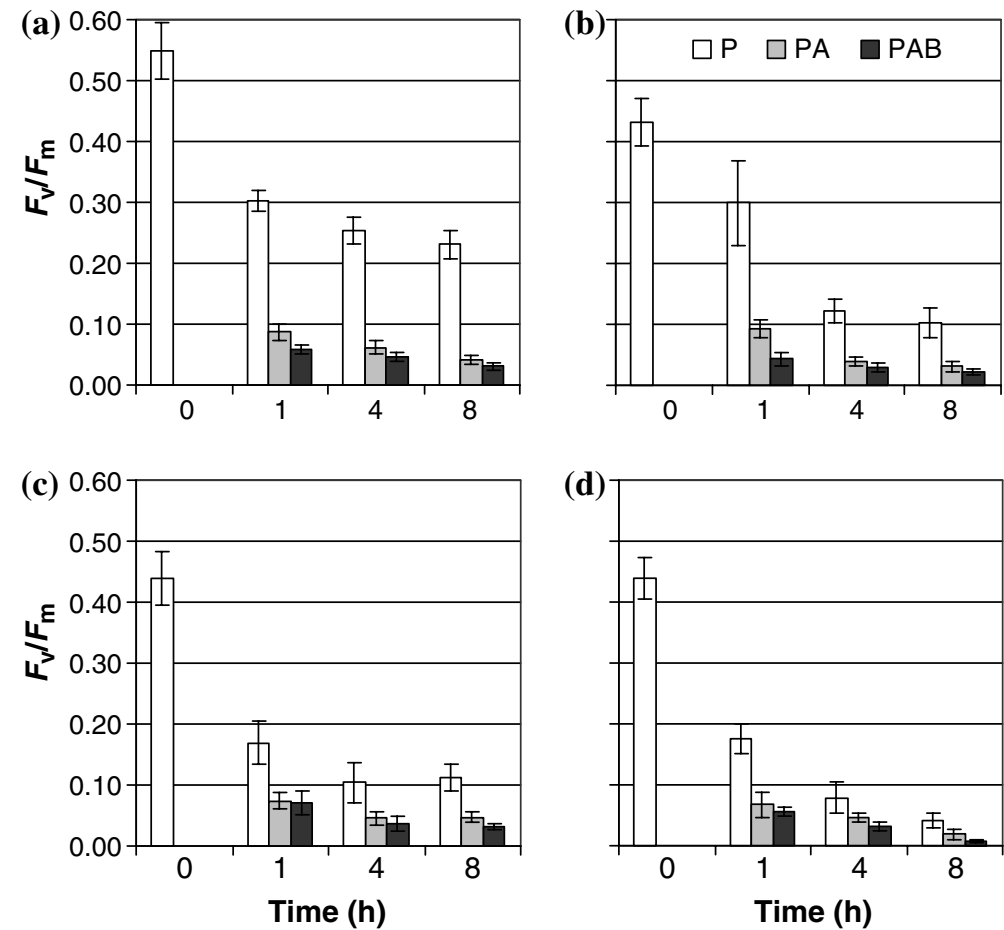

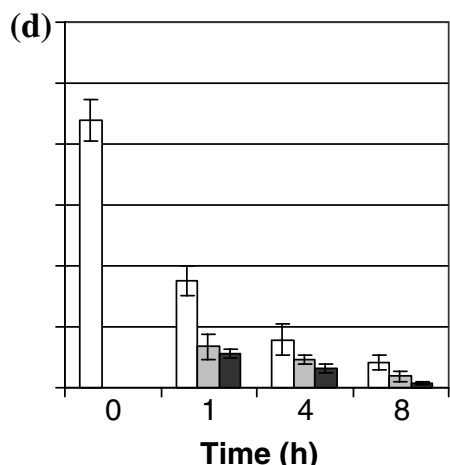

Table 3 Multiple analysis of variance (MANOVA) and significance values for the main effects and interactions of light treatment (spectral irradiance compose of $\mathrm{P}, \mathrm{PA}$, and $\mathrm{PAB}$ ) and exposure time on photosynthetic efficiency of zoospores in four species of Laminariales from Spitsbergen (*significant; ns, not significant)

\begin{tabular}{lllrr}
\hline Species & Source of variation & df & $F$-value & $P$-value \\
\hline S. dermatodea & Spectral irradiance $(A)$ & 2 & 1028.4 & $<0.001^{*}$ \\
& Exposure time $(B)$ & 2 & 56.1 & $<0.001^{*}$ \\
& $A^{*} B$ & 4 & 1.1 & $0.392^{\text {ns }}$ \\
A. esculenta & Spectral irradiance $(A)$ & 2 & 211.0 & $<0.001^{*}$ \\
& Exposure time $(B)$ & 2 & 80.2 & $<0.001^{*}$ \\
& $A^{*} B$ & 4 & 11.1 & $<0.001^{*}$ \\
L. digitata & Spectral irradiance $(A)$ & 2 & 72.4 & $<0.001^{*}$ \\
& Exposure time $(B$ & 2 & 21.0 & $<0.001^{*}$ \\
L. saccharina & $A^{*} B$ & 4 & 1.3 & $0.294^{\text {ns }}$ \\
& Spectral irradiance $(A)$ & 2 & 80.7 & $<0.001^{*}$ \\
& Exposure time $(B)$ & 2 & 114.5 & $<0.001^{*}$ \\
& $A^{*} B$ & 4 & 5.0 & $0.003^{*}$ \\
\hline
\end{tabular}

UV-A radiation delayed photosynthetic recovery in all species except in $S$. dermatodea zoospores pre-exposed to $1 \mathrm{~h} \mathrm{PA}$, where photosynthetic recovery is not significantly different with $\mathrm{P}$ treatment. Exposure to light supplemented with the whole UV spectrum (PAB) significantly delayed photosynthetic recovery. Zoospores exposed to PAB had a significantly lower recovery rate compared to $\mathrm{P}$ in all species and exposure time and to PA in all species except in $4 \mathrm{~h}$-exposed A. esculenta and $1 \mathrm{~h}$-exposed L. digitata where no significant difference was observed between PA and PAB treatments (Fig. 3).

\section{Discussion}

This study confirms that photosynthesis of kelp zoospores is shade adapted and that UVR causes a much stronger photoinhibition of photosynthesis compared to adult sporophytes. Moreover, it is the first report on the kinetics of photosynthetic recovery of kelp zoospores which is dependent on spectral quality, exposure time and species, and which reflects the depth distribution of the adult sporophytes.

The $I_{k}$ estimates derived from $\mathrm{rETR}_{\max }$ as minimum saturating incident irradiance $\left(I_{\mathrm{o}}\right)$ points to the shade adaptation of photosynthesis in kelp zoospores. The values between 13 and $18 \mu$ mol photons $\mathrm{m}^{-2} \mathrm{~s}^{-1}$ are much lower compared to cold temperate Laminaria species, which are characterized by $I_{k}$ values ranging from 20 to $40 \mu \mathrm{mol}$ photons $\mathrm{m}^{-2} \mathrm{~s}^{-1}$ (Roleda et al. 2005). Spores of subtropical (warm temperate) kelp species showed even higher $I_{k}$ values ranging from 41 to $77 \mu \mathrm{mol}$ photons $\mathrm{m}^{-2} \mathrm{~s}^{-1}$ (Amsler and Neushul 1991). The decreasing $I_{k}$ from the mid- to high-latitudes corresponds to the decreasing solar irradiance from the equator to the polar region. A similar relation has been demonstrated in adult macrothalli of seaweeds from polar to tropical regions (Lüning 1990; Wiencke et al. 1993; Weykam et al. 1996).

The photosynthesis-irradiance parameters determined here reflect the depth distribution of the adult sporophytes. The shallow water species $S$. dermatodea has $\mathrm{rETR}_{\max }$ and $I_{k}$ values considerably above the values of the other three 
Fig. 3 Time-series recovery in the mean optimum quantum yield $\left(F_{\mathrm{v}} / F_{\mathrm{m}}\right)$ of zoospores after exposure to photosynthetically active radiation $(\mathrm{PAR}=\mathrm{P})$, $\mathrm{PAR}$ + UV-A (PA), and PAR + UV$\mathrm{A}+\mathrm{UV}-\mathrm{B}(\mathrm{PAB})$ at different exposure times (vertical columns) in (a) Saccorhiza dermatodea (b) Alaria esculenta (c) Laminaria digitata and (d) Laminaria saccharina (horizontal columns) expressed as percent recovery of disturbed control. Controls were untreated samples cultured at dim white light $\left(8 \pm 2 \mu \mathrm{mol}\right.$ photons $\mathrm{m}^{-2}$ $\left.\mathrm{s}^{-1}\right)$. Vertical bars are standard deviations ( $\mathrm{SD}, \mathrm{n}=5)$ ). Repeated measures analysis of variance (RMANOVA, $P<0.01$ ) showed significant difference between treatments. Letters on graph show result of Duncan's multiple range test (DMRT, $P=0.05$ ); different letters refer to significant difference between treatments

\section{Exposure time of treatment (h)}
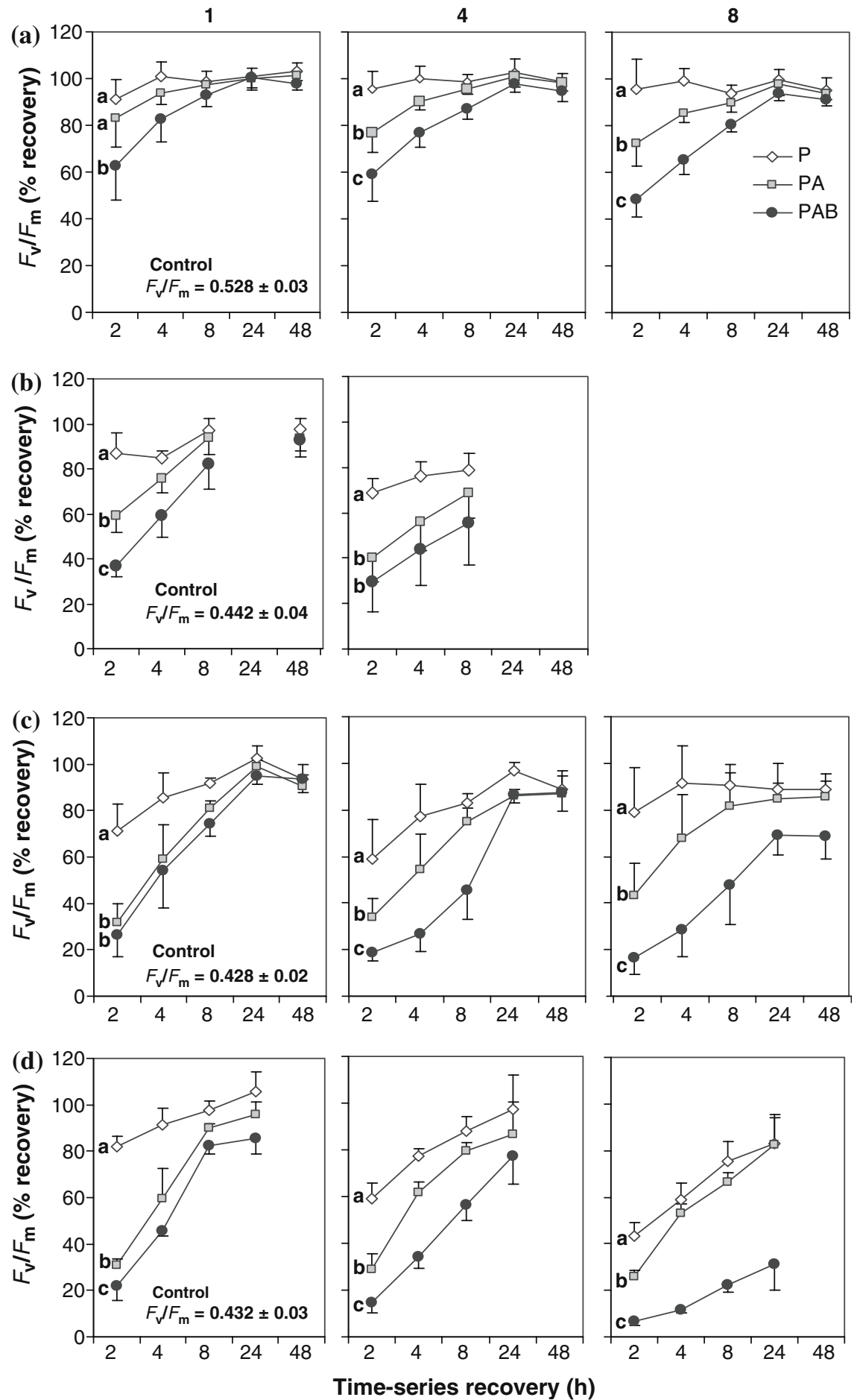

species from deeper waters. The strongest shade adaptation is present in the mid- to lower-sublittoral species L. saccharina. This species is characterized by a very low $I_{k}$ value and is the only species photoinhibited at actinic light levels $\geq 68 \mu \mathrm{mol}$ photons $\mathrm{m}^{-2} \mathrm{~s}^{-1}$. A similar trend was observed in the P-I curve parameters among zoospores of Helgolandic Laminaria species (Roleda et al. 2005) and in adult macrothalli of numerous species (Lüning 1990; Weykam et al. 1996).

Depression in maximum quantum yield $\left(F_{\mathrm{v}} / F_{\mathrm{m}}\right)$ of PSII was lower in Saccorhiza dermatodea and Alaria esculenta compared to the two Laminaria species. Reduction of photosynthetic capacity and quantum efficiency in plants exposed to high fluence rates of PAR is a protective 
strategy to dissipate excess energy absorbed by the PSII as heat to avoid photodamage. This photoprotection process, also known as dynamic photoinhibition, is regulated to dissipate excessive radiation (Osmond 1994). This process may also be modulated by an increase in the zeaxanthin content of the PSII antenna (Adams and Demming-Adams 1992) and/or by increasing the amount of inactive PSII centers thereby protecting the photosynthetically active centers (Öquist and Chow 1992). In contrast, impairment of PSII reaction center D1 protein, the major target of oxidative damage in PSII (Aro et al. 1993) induces photoinactivation. This occurs in seaweeds or propagules of seaweeds growing in the lower sublittoral zone when exposed to high irradiances. These specimens have a lower ability to down regulate photosynthesis through photoprotection (Franklin et al. 2003). After photoinhibition, recovery of photosynthesis often requires dim white light conditions (Hanelt et al. 1992). If low-light adaptation is the general feature of brown algal zoospores, as presented here, excessive light may exert a significant effect on their survival in the water column.

UVR exerts an additional stress on the photosynthetic apparatus of zoospores. Although the measurable effects of both PAR and UVR in the reduction of photosynthetic efficiency are similar, the mechanisms behind PAR- and UVR-induced inhibition of photosynthesis are different (Hanelt et al. 2003). UV radiation depresses photosynthetic performance by damaging the oxidizing site and reaction center of PSII (Franklin et al. 2003; Turcsányi and Vass 2002; Grzymski et al. 2001). Both UV and visible light was, however, found to induce photoinhibition when Manganese (Mn) ion is released into the thylakoid lumen. Mn-depleted oxygen-evolving complex induces oxidative damage to the PSII reaction center because $\mathrm{P}-680^{+}$cannot be reduced normally (Hakala et al. 2005). Other more direct impacts of UVR on photosynthesis includes its absorption by aromatic and sulfhydryl-containing biomolecules causing direct molecular damage (Vass 1997) and, by proteins and DNA forming cyclobutane-pyrimidine dimers (CPDs, Setlow 1974). Efficient DNA damage repair and recovery of PSII damage contributed to higher germination success in spores of the upper sublittoral L. digitata compared to the lower sublittoral L. hyperborea from Helgoland (Roleda et al. 2005). In S. dermatodea, an increase in number and size of phlorotannin-containing physodes was observed after UV exposure which contributed protection against cellular damage, which enhanced germination rate (Wiencke et al. 2004).

The difference in the recovery of photosynthetic capacity after photoprotection and photodamage has been defined within a time frame vaguely described as 'within several minutes' and 'several hours', respectively (Franklin et al. 2003; Hanelt et al. 2003). This definition is dependent on chlorophyll antenna size and number of chloroplast in different life stages of macroalgae. In unicellular chlorophytes Dunaliella salina Teod., cells with larger Chl antenna was found to incur significantly higher rate of photodamage (Baroli and Melis 1998). Zoospores with only one chloroplast per cell (Henry and Cole 1982) are more susceptible to photodamage compared to multi-cellular life history stages. Incident UV-B radiation can easily penetrate through the thin plasmalemma of zoospores damaging the chloroplast. Intracellular self-shading in macroalgal thalli and the nonuniformly shaped and unevenly spaced cells cause multiple scattering (Grzymski et al. 1997), which can attenuate up to $95 \%$ of the incident UV-B radiation and yet transmit between $70 \%$ and $80 \%$ of the visible radiation (Robberecht and Caldwell 1983). Thus radiation is selectively filtered to effectively remove the short UV wavelengths before reaching the chloroplasts. With several variables to consider in our experimental setup, we were constrained to measure photosynthetic recovery only after $2 \mathrm{~h}$ post-cultivation in low white light to avoid parallel measurements. Despite this limitation, we suggest that reduction in photosynthetic efficiency in PARexposed $S$. dermatodea zoospores is due to photoprotection while in PAR-exposed L. saccharina is due to photoinactivation. Zoospores of $S$. dermatodea were able to down regulate photosynthesis through dynamic photoinhibition while incomplete recovery in zoospores of L. saccharina results from the longer time required for de novo synthesis and replacement of damaged D1 protein in the thylakoid membrane. Future studies on D1 protein and zeaxanthin synthesis (Adams and Demming-Adams 1992; Andersson et al. 1992; Bischof et al. 2002) are necessary to confirm this hypothesis. Damage to reaction centers of PSII affecting the water-oxidizing complex (Turcsányi and Vass 2002) might be responsible for the lower and delayed photosynthetic recovery in UVR-exposed zoospores. The life stage-dependent photodamage and synthesis of new D1 protein can be investigated using lincomycin, which inhibits plastidial protein synthesis, to map plastid transcripts that are extensively and rapidly processed (Franklin and Larkum 1997; Bergo et al. 2003; Yakandawala et al. 2003).

Based on the result of this laboratory study, spore viability and eventual successful recruitment is dependent on the residence time of zoospores within the euphotic zone where they might be exposed to excessive radiation. The residence time in the euphotic zone is affected by several variables such as the position of the spore producing tissue, swimming speed and sedimentation rate, phototaxis and hydrodynamic conditions. For example, Saccorhiza polyschides (Lightfoot) Batters and Nereocystis species release spores from the upper part of the thallus which is close to the water surface, while Macrocystis C. Agardh 
and Alaria have their reproductive sporophylls situated basally, just above the holdfast (Norton 1992). Negative phototaxis in Saccorhiza polyschides may aid downward settlement to low-light environment under the canopy of adult kelp and undergrowths while positive phototaxis in Ectocarpus Lyngbye may compensate for the low release height resulting from the plant's small stature to capture required light for photosynthesis to allow sufficient net production. On the other hand, sporophylls of Alaria esculenta (L.) Grev. release more zoospores with water motion compared to calm condition (Gordon and Brawley 2004). Fertile plant parts can also drift away, survive for a long period and release propagules within the euphotic zone. Excessive turbulence could not only hinder sedimentation of spores to the low-light microenvironment at depths but could also diffuse gametophytes at distance hindering settlement of opposite sex within reach that could entail failure of sporophyte development (Norton 1992).

To estimate the ecological impact of enhanced UVR, reproductive seasonality as well as diel periodicity in zoospore release among different kelp species should be considered. For example, formation of sporogenic tissue in Laminariales have been reported to be either seasonal (Roleda et al. 2005; Wiencke et al. 2006) or perennial (Chapman 1984, Joska and Bolton 1987). Maximum spore production and release in Ecklonia maxima (Osbeck) Papenf. occurs in spring and early summer (Joska and Bolton 1987). Winter reproduction in the lower sublittoral Laminaria hyperborea in Helgoland is thought to be a strategy to avoid reproductive failure due to the relative sensitivity of their zoospores to PAR and UVR (Roleda et al. 2005). Spore release of Nereocystis luetkeana (Mertens) Postels et Ruprecht at dawn is suggested to be a mechanism to maximize photosynthetic potential of the spores (Amsler and Neushul 1989).

Despite the higher UVR: PAR ratio applied in this laboratory experiment, results obtained on kinetics of photosynthetic recovery support the results on field germination experiments performed on $S$. dermatodea, A. esculenta, and $L$. digitata. In these experiments, zoospores were exposed to ambient solar radiation at different water depth and cultivated in the laboratory at low-light condition, simulating low-light microenvironment upon settlement (Wiencke et al. 2006). In all species, germination rates of zoospores exposed to PAR were similar at all depths investigated. However, UV radiation affected germination rates in different ways, depending on the species and the water depth. Zoospores of $S$. dermatodea germinated in all water depth while germination of zoospores of A. esculenta was strongly inhibited in $0.5 \mathrm{~m}$ water depth. The most susceptible species was $L$. digitata, whose zoospores failed to germinate in 0.5 and $1.0 \mathrm{~m}$-water depths. This pattern is at least partly based on the differential photosynthetic recovery of the zoospores after UV exposure, shown in the present study. The degree of UV exposure depends on several variables such as the weather condition, the content of UV absorbing ozone in the atmosphere and the optical properties of the water column. Stratospheric ozone depletion is highest in spring, at the same time the seawater is very clear (Hanelt et al. 2001). So the risk to be exposed to the damaging UV radiation is highest during this time of the year.

Acknowledgements We thank A. Gruber for technical help, the diving team of Spitsbergen 2004 field campaign especially M. Schwanitz for collecting fertile plant material and the Ny- Alesund International Arctic Environmental Research and Monitoring Facility for support.

\section{References}

Adams III WW, Demming-Adams B (1992) Operation of xanthophyll cycle in higher plants in response to diurnal changes in incident sunlight. Planta 186:390-398

Amsler CD, Neushul M (1989) Diel periodicity of spore release from kelp Nereocystis luetkeana (Mertens) Postels et Ruprecht. J Exp Mar Biol Ecol 134:117-127

Amsler CD, Neushul M (1991) Photosynthetic physiology and chemical composition of spores of the kelps Macrocystis pyrifera, Nereocystis luetkeana, Laminaria farlowii, and Pterygophora californica (Phaeophyceae). J Phycol 27:26-34

Andersson B, Salter AH, Virgin I, Vass I, Styring S (1992) Photodamage to Photosystem II- primary and secondary events. J Photochem Photobiol B: Biol 15: 15-31

Aro EM, Virgin I, Andersson B (1993) Photoinhibition of photosystem II: inactivation, protein damage and turnover. Biochim Biophys Acta 1143:113-134

Baroli I, Melis A (1998) Photoinhibitory damage is modulated by the rate of photosynthesis and by the photosystem II light-harvesting chlorophyll antenna size. Planta 295:288-296

Bergo E, Segalla A, Giacometti GM, Tarantino D, Soave C, Andreucci F, Barbato R (2003) Role of visible light in the recovery of photosystem II structure and function from ultraviolet-B stress in higher plants. J Exp Bot 54:1665-1673

Bischof K, Hanelt D, Tüg H, Karsten U, Brouwer PEM, Wiencke C (1998) Acclimation of brown algal photosynthesis to ultraviolet radiation in Arctic coastal waters (Spitsbergen, Norway). Polar Biol 20:388-395

Bischof K, Kräbs G, Wiencke C, Hanelt D (2002) Solar ultraviolet radiation affects the activity of ribulose-1,5-biphosphate carboxylase-oxygenase and the composition of photosynthetic and xanthophyll cycle pigments in the intertidal green alga Ulva lactuca L. Planta 215:502-509

Chalker BE, Dunlap WC, Oliver JK (1983) Bathymetric adaptations of reef-building corals at Davies Reef, Great Barrier Reef, Australia. II. Light saturation curves for photosynthesis and respiration. J Exp Mar Biol Ecol 73:37-56

Chapman ARO (1984) Reproduction, recruitment and mortality in two species of Laminaria in southwest Nova Scotia. J Exp Mar Biol Ecol 78:99-109

Coon DA, Neushul M, Charters AC (1972) The settling behaviour of marine algal spores. In: Nisizawa $K$ (ed) Proceedings 7th International Seaweed Symposium, University of Tokyo Press, Tokyo, pp 237-242 
Cordi B, Donkin ME, Peloquin J, Price DN, Depledge MH (2001) The influence of UV-B radiation on the reproductive cells of the intertidal macroalga, Enteromorpha intestinalis. Aquat Toxicol $56: 1-11$

Deysher L , Norton TA (1982) Dispersal and colonization in Sargassum muticum (Yendo) Fensholt. J Exp Mar Biol Ecol 56:179-195

Dring MJ, Makarov V, Schoschina E, Lorenz M, Lüning K (1996) Influence of ultraviolet-radiation on chlorophyll fluorescence and growth in different life-history stages of three species of Laminaria (Phaeophyta). Mar Biol 126:183-191

Franklin LA, Larkum AWD (1997) Multiple strategies for a high light existence in a tropical marine macroalga. Photosyn Res 53:149-159

Franklin LA, Osmond CB, Larkum AWD (2003) Photoinhibition, UV-B and algal photosynthesis. In: Larkum AW, Douglas SE, Raven JA (eds) Photosynthesis in Algae. Kluwer Academic Publishers, The Netherlands, pp 351-384

Gathen P von der, Rex M, Harris NRP, Lucic D, Knudsen BM, Braathen GO, De Backer H, Fabian R, Fast H, Gil M, Kyrö E, Mikkelsen IS, Rummukainen M, Stähelin J, Varotsos C (1995) Observational evidence for chemical ozone depletion over the Arctic in winter 1991-92. Nature 375:131-134

Gordon R, Brawley SH (2004) Effects of water motion on propagule release from algae with complex life histories. Mar Biol 145:21-29

Grzymski J, Johnsen G, Sakshaug E (1997) The significance of intracellular self-shading on the biooptical properties of brown, red, and green macroalgae. J Phycol 33:408-414

Grzymski J, Orrico C, Schofield OM (2001) Monochromatic ultraviolet light induced damage to Photosystem II efficiency and carbon fixation in the marine diatom Thalassiosira pseudonana (3H). Photosynth Res 68:181-192

Hakala M, Tuominen I, Keranen M, Tyystjarvi T, Tyystjarvi E (2005) Evidence for the role of the oxygen-evolving manganese complex in photoinhibition of photosystem II. Biochim Biophys Acta 1706:68-80

Hanelt D (1998) Capability of dynamic photoinhibition in Arctic macroalgae is related to their depth distribution. Mar Biol 131:361-369

Hanelt D, Huppertz K, Nultsch W (1992) Photoinhibition of photosynthesis and its recovery in red algae. Bot Acta 105:278-284

Hanelt D, Wiencke C, Karsten U, Nultsch W (1997) Photoinhibition and recovery after high light stress in different developmental and life-history stages of Laminaria saccharina (Phaeophyta). J Phycol 33:387-395

Hanelt D, Tüg GH, Bischof K, Groß C, Lippert H, Sawall T, Wiencke C (2001) Light regime in an Arctic fjord: a study related to stratospheric ozone depletion as a basis for determination of UV effects on algal growth. Mar Biol 138:649-658

Hanelt D, Wiencke C, Bischof K (2003) Photosynthesis in marine macrolage. In: Larkum AW, Douglas SE, Raven JA (eds) Photosynthesis in Algae. Kluwer Academic Publishers, The Netherlands, pp 413-435

Henry EC, Cole KM (1982) Ultrastructure of swarmers in the Laminariales (Phaeophyceae), I. Zoospores. J Phycol 18:550-569

Jassby AD, Platt T (1976) Mathematical formulation of the relationship between photosynthesis and light for phytoplankton. Limnol Oceanogr 21:540-547

Joska MAP, Bolton JJ (1987) In situ measurement of zoospore release and seasonality of reproduction in Ecklonia maxima (Alariaceae, Laminariales). Br Phycol J 22:209-214

Kessler JO (1985) Hydrodynamic focusing of motile algal cells. Nature 313:218-220

Lüning K (1990) Seaweeds. Their environment, biogeography and ecophysiology. Wiley-Interscience, New York
Melis A (1999) Photosystem-II damage and repair cycle in chloroplasts: what modulates the rate of photodamage in vivo? Trends Plant Sci 4:130-135

Nishiyama Y, Allakhverdiev SI, Yamamoto H, Hayashi H, Murata N (2004) Singlet oxygen inhibits the repair of photosystem II by suppressing the translation elongation of the D1 protein in Synechocystis sp. PCC 6803. Biochemistry 43:11321-11330

Nishiyama Y, Allakhverdiev SI, Murata N (2005) Inhibition of the repair of photosystem II by oxidative stress in cyanobacteria. Photosyn Res 84:1-7

Norton TA (1992) Dispersal by macroalgae. Br Phycol J 27:293-301

Norton TA, Fetter R (1981) The settlement of Sargassum muticum propagules in stationary and flowing water. J Mar Biol Ass UK 61:929-940

Ohnishi N, Allakhverdiev SI, Takahashi S, Higashi S, Watanabe M, Nishiyama Y, Murata N (2005) Two-step mechanism of photodamage to photosystem II: step 1 occurs at the oxygen-evolving complex and step 2 occurs at the photochemical reaction center. Biochemistry 44:8494-8499

Öquist G, Chow WS (1992) On the relationship between the quantum yield of Photosystem II electron transport, as determined by chlorophyll fluorescence, and the quantum yield of $\mathrm{CO}_{2}$-dependent $\mathrm{O}_{2}$ evolution. Photosynth Res 33:51-62

Osmond CB (1994) What is photoinhibition? Some insights from comparisons of shade and sun plant. In: Baker NR, Bowyer JR (eds) Photoinhibition of photosynthesis, from the molecular mechanisms to the field. BIOS Scientific Publ., Oxford, pp 1-24

Purcell EM (1977) Life at low Reynolds number. Am J Phys 45:3-11

Richter M, Rühle W, Wild A (1990) Studies on the mechanism of Photosystem II photoinhibition I. A two-step degradation of D1protein. Photosynth Res 24:229-235

Robberecht R, Caldwell MM (1983) Protective mechanisms and acclimation to solar ultraviolet-B radiation in Oenothera stricta. Plant Cell Environ 6:477-485

Roleda MY, van de Poll WH, Hanelt D, Wiencke C (2004) PAR and UVBR effects on photosynthesis, viability, growth and DNA in different life stages of two coexisting Gigartinales: implications for recruitment and zonation pattern. Mar Ecol Prog Ser 281:37-50

Roleda MY, Wiencke C, Hanelt D, van de Poll WH, Gruber A (2005) Sensitivity of Laminariales zoospores from Helgoland (North Sea) to ultraviolet and photosynthetically active radiation: implications for depth distribution and seasonal reproduction. Plant Cell Environ 28:466-479

Setlow RB (1974) The wavelengths in sunlight effective in producing skin cancer: a theoretical analysis. Proc Natl Acad Sci USA 71:3363-3366

Stähelin J, Harris NRP, Appenzeller C, Eberhard J (2001) Ozone trends: a review. Rev Geophy 39:231-290

Turcsányi E, Vass I (2002) Effect of UV-A radiation on photosynthetic electron transport. Acta Biol Szeged 46:171-173

Vass I (1997) Adverse effects of UV-B light on the structure and function of the photosynthetic apparatus. In: Pessarakli M (eds) Handbook of photosynthesis. Marcel Dekker Inc., New York, pp 931-949

Weykam G, Gómez I, Wiencke C, Iken K, Klöser H (1996) Photosynthetic characteristics and C:N ratios of macroalgae from King George Island (Antarctica). J Exp Mar Biol Ecol 204:1-22

Wiencke C, Rahmel J, Karsten U, Weykam G, Kirst GO (1993) Photosynthesis of marine macroalgae from Antarctica: light and temperature requirements. Bot Acta 106:78-87

Wiencke C, Gómez I, Pakker H, Flores-Moya A, Altamirano M, Hanelt D, Bischof K, Figueroa FL (2000) Impact of UV radiation on viability, photosynthetic characteristics and DNA of brown algal zoospores: implications for depth zonation. Mar Ecol Prog Ser 197:217-229 
Wiencke C, Clayton MN, Schoenwaelder M (2004) Sensitivity and acclimation to UV radiation of zoospores from five species of Laminariales from the Arctic. Mar Biol 145:31-39

Wiencke C, Roleda MY, Gruber A, Clayton MN, Bischof K (2006) Susceptibility of zoospores to UV radiation determines upper depth distribution limit of Arctic kelps: evidence through field experiments. J Ecol 94:455-463
Yakandawala N, Lupi C, Bilang R, Potrykus I (2003) Lincomycin treatment: a simple method to differentiate primary and processed transcripts in rice (Oryza sativa L.) chloroplast. Plant Mol Biol Rep 21:241-247 